\title{
ISOLATION AND SCREENING OF THERMOPHILIC CELLULOLYTIC BACTERIA FROM COMPOST PILES
}

\author{
A. Acharya*, D.R. Joshi*, K. Shrestha** and D.R. Bhatta* \\ *Central Department of Microbiology, Tribhuvan university, Kirtipur, Nepal. \\ ** Natural Product Chemistry Research Laboratory, Nepal Academy of Science and Technology (NAST) Khumaltar, \\ Lalitpur, Nepal.
}

\begin{abstract}
Cellulose, a major polysaccharide found in agricultural residues and industrial and municipal wastes. In the present study thermophilic cellulolytic microorganisms were isolated. The isolates were tested for their cellulytic activity. The enzyme production from potent isolates was optimised using cellulose basal broth medium. Activity of partially purified enzyme was determined. The most potent thermophilic cellulolytic isolates were identified as Bacillus subtilis. The crude cellulase enzyme concentrated at $80-85 \%$ ammonium sulfate produced highest zone of hydrolysis. The enzymatic degradation of cellulose waste has been suggested as a feasible alternative for the conversion of lignocelluloses substrate into fermentable sugars and application for biofuel production.
\end{abstract}

Keywords: Thermophilic cellulolytic bacteria; Cellulase enzyme; Compost piles.

\section{INTRODUCTION}

Cellulose is biologically renewable resource abundantly found in agriculture waste. The cellulosic waste materialcan be hydrolysed to glucose and other soluble sugars by using cellulase enzymes of bacteria and fungi. The reducing sugars obtained can be further used for the production of ethanol as biofuel (Eriksson et al., 2002). The potential cellulose producing bacteria are Cellulomonas, Pseudomonas, Thermoactinomycetes and Bacillus spp.(Godana, 2007).

It has been estimated that $7.2 \times 10^{11}$ tonnes of cellulose is reserved in plants and that the yearly production of cellulose is $4 \times 10^{10}$ tonnes (Coughlan, 1985). Cellulases include three main types of enzymes, endoglucanases, cellobiohydrolases or exoglucanases and â-glucosidases. These enzymes can either be free or grouped in a multicomponent enzyme complex (cellulosome) found in anaerobic cellulolytic bacteria (Mosier et al., 1999).

Enzymatic hydrolysis is an economic process in the conversion of cellulose to easily fermentable low cost sugars (Muthuvelayudham and Viruthagiri, 2006). Thermo philic filamentus fungi, and actinomycetes are widely used for industrial production of specific, stable and active enzymes (Mach and Zeilinger, 2003; Haki and Rakshit, 2003).

Present study aimed to isolate and screen potential thermophilic cellulolytic microorganisms from compost piles.

\section{METHODOLOGY}

The present study was conducted at the laboratory of Nepal Academy of Science and Technology (NAST) from January 2009 to October 2010.

\section{Enrichment, Isolation and Screening of Thermophilic Cellulytic Bacteria}

A total of 13 different compost samples (temperature $\geq$ $50^{\circ} \mathrm{C}$ ) were collected in sterile containers. The compost piles were air dry and heated at $55^{\circ} \mathrm{C}$ for 1 week and air drying to reduce the mesophiles and anaerobic isolates. Two protocols were used for isolation of thermophilic cellulase producer's bacteria. One gm of compost piles was serially diluted in order to reduce the initial number of microorganisms. Appropriate dilution was then both direct spread plated on CMC agar medium or enriched Cellulose broth and plating (spread) on (CMC) Agar. All incubations were done at $55^{\circ} \mathrm{C}$ for 2-4 weeks with shaking at $120 \mathrm{rpm}$ in a controlled environment shaker (Ibrahim and El-diwany, 2007).

\section{Screening of Potent Cellulytic Thermophilic Isolates}

1\% congo red indicator (El-Sersy et al., 2010) was applied for screening of cellulolytic bacterial isolates. The plates were flooded with $1 \%$ congo red indicator and left for 15 mins followed by adding $1 \mathrm{M} \mathrm{NaCl}$ solution and again left for another $15 \mathrm{~min}$. then the development of halo zone around the colony indicated the cellulose hydrolysis. If not clear, 0.1N HCL was added to make further clearer zone (Wood and Bhat, 1988 and El-Sersy et al., 2010).

\section{Identification of Thermotolerent and Thermophilic Cellulytic Microorganism}

Representative bacterial isolates exhibiting high cellulytic activity were selected for identification according to method described by Bergey's Manuals of Systematic

Author for Correspondence: A. Acharya, Central Department of Microbiology, Tribhuvan university, Kirtipur, Nepal. Email: acharya_amrit@hotmail.com. 
Bacteriology and Determinative Bacteriology (Ghazifard et al., 2001; Altai et al., 1989).

\section{Enzyme Production and activity determination}

Batch fermentation was adopted for enzyme production was done by inoculating $5 \mathrm{ml}$ of each pre-fermenter inoculum into $500 \mathrm{ml}$-Erlenmeyer flasks containing the same $100 \mathrm{ml}$ cellulose basal broth medium and maintained the final inoculums size 5\%. The flasks were shaken at $150 \mathrm{rpm}$ and incubated at $50^{\circ} \mathrm{C}$ for $5-7$ days (Omojasola et al., 2008). The submerged cultures were carried out in duplicate. The previously studied different Basal mediums were tested for maximum production of cellulase enzyme. The fermentation was monitored for cellulase activity, reducing sugar and protein content. Activities of cellulase enzyme system secreted into the culture medium of potent isolates were estimated in accordance with following methods listed by Wood and Bhat (1988). The evaluation of crude enzyme Cellulolytic activity was carried out for measuring zone of hydrolysis on 1\% CMC agar medium by Plate diffusion assay method (Oyekola, 2003). Fermentation was monitored daywise by estimating reducing sugars by DNS method (Miller, 1959).
Enzyme activity was determined spectrophotometrically as adapted from the recommendations of the Commission of Biotechnology (Wood and Bhat, 1988).

\section{Protein estimation}

The protein content of the culture supernatant was determined by Bradford et al., (1976).

\section{Partial Purification and Evaluation of Cellulase Enzyme}

Partial Purification of the enzyme from culture supernatant was done by Ammonium sulfate concentration method (Aboul-Enein et al., 2010; Wood and Bhat (1988).

\section{Characterization of Enzyme}

\section{Thermal Stability:}

To determine the thermal stability of the enzyme, the respective isolates of enzyme was incubated in $0.05 \mathrm{M}$ phosphate buffer of $\mathrm{pH} 7.0$ and $0.05 \mathrm{M}$ sodium citrate $\mathrm{pH} 4.8$ for 1 hour at temperature ranging from $30-80^{\circ} \mathrm{C}$ (Oyekola, 2003; Ariffin et al., 2006).

Table 1: Colony morphology and Microscopic characteristics of cellulytic Bacterial isolates.

\begin{tabular}{|c|c|c|}
\hline Presumptive genera & Colonies morphology & Microscopic characteristics \\
\hline Amphibacillus spp. & $\begin{array}{l}\text { circular, convex and white, } \\
1-3 \mathrm{~mm}\end{array}$ & $\begin{array}{l}\text { A facultatively anaerobic, alkaliphilic, spore-forming, Gram- } \\
\text { positive-staining rod, endospore are oval and central, somewhat } \\
\text { swelling cell, motile by peritrichous flagella. }\end{array}$ \\
\hline Bacillus licheniformis & $\begin{array}{l}\text { Rhizoid convex } 0.5 \mathrm{~cm} \\
\text { rough dry opaque, yellow }\end{array}$ & $\begin{array}{l}\text { Rough and Smooth forms, mucoid, short baciili and also } \\
\text { filamentous type , flagellate, non sporing }\end{array}$ \\
\hline Bacillus spp. & $\begin{array}{l}\text { Round translucent colony } \\
\text { with smooth edges. Gram- } \\
\text { positive rods with } \\
\text { endospores. Motile. }\end{array}$ & $\begin{array}{l}\text { Rod shaped and straight, } 0.5-2.5 * 1.2-10 \text { um in size are often arrane } \\
\text { in pairs or chain, with rounded or square end. Gram positive, } \\
\text { endospore are oval or sometime round or cylindrical, motile by } \\
\text { peritrichous flagella. }\end{array}$ \\
\hline Bacillus subtilis & $\begin{array}{l}\text { Irregular raised } 1.0 \mathrm{~cm} \\
\text { rough / dry opaque white }\end{array}$ & $\begin{array}{l}\text { Rod-shaped Gram positive bacteria, motile by peritrichous } \\
\text { flagella and aerobic rod-shaped, and has the ability to form a } \\
\text { tough, endospore }\end{array}$ \\
\hline $\begin{array}{l}\text { Cellulomonas } \\
\text { cellulans }\end{array}$ & $\begin{array}{l}\text { Colonies are, circular, } \\
\text { convex, } \\
\text { white, and glistening }\end{array}$ & $\begin{array}{l}\text { In young culture, slender, irregular rods, } 0.5-0.6 * 2-5 \text { um in size are } \\
\text { straight or slightly curve, some rods are in pairs at an angle to each } \\
\text { other giving v formation, rods occasionally slow branching, but no } \\
\text { mycelium is formed. } \\
\text { In old culture- rods are usually short, afew cocci may occur, } \\
\text { Gram positive easily decolorized, often motile by one or two } \\
\text { flagella, non sporing, non acid fast. }\end{array}$ \\
\hline Clostridium spp. & $\begin{array}{l}\text { Circular raised } 0.7 \mathrm{~cm} \text {, } \\
\text { smooth glistering, mucoid, } \\
\text { translucent cream }\end{array}$ & $\begin{array}{l}\text { Circular raised colony with } 0.7 \mathrm{~cm} \text { diameter, non-motile, Gram- } \\
\text { negative short rods. }\end{array}$ \\
\hline Geobacillus spp. & $\begin{array}{l}\text { Colonies are round, } \\
\text { convex, mucoid and } \\
\text { colorless. }\end{array}$ & $\begin{array}{l}\text { Aerobic or facultatively anaerobic, rod-shaped, either occurring } \\
\text { short chains and motile by means of peritrichous flagella, Gram } \\
\text { positive bacterium, sporulating rods with ellipsoidal endospores. }\end{array}$ \\
\hline Penibacillus spp. & $\begin{array}{l}\text { Colonies on are circular, } \\
\text { flat, white/cream, opaque } \\
\text { and usually } 1-3 \mathrm{~mm} \text { in } \\
\text { diameter }\end{array}$ & $\begin{array}{l}\text { Aerobic or facultatively anaerobic, Spore-forming rods, } 0.8- \\
0.9 \mu \mathrm{m} \text { wide and } 4.0-4.2 \mu \mathrm{m} \text { long. } \\
\text { Gram-variable., rods .Motile by means of peritrichous flagella. } \\
\text { Ellipsoidal spores are formed in swollen sporangia and occupy a } \\
\text { subterminal position in the cell. }\end{array}$ \\
\hline
\end{tabular}


Table 2: Cellulytic activity of bacterial isolates

\begin{tabular}{|c|c|c|}
\hline S.N. & Isolates & $\begin{array}{l}\text { Cellulytic zone } \\
\text { of hydrolysis } \\
\text { (well size } 6 \mathrm{~mm} \text { ) }\end{array}$ \\
\hline 1 & Bacillus subtilis* & 26 \\
\hline 2 & Cellulomonas cellulans $* *$ & 22 \\
\hline 3 & Geobacillus spp. ** & 24 \\
\hline 4 & Penibacillus spp. * & 23 \\
\hline 5 & Bacillus spp. ${ }^{* *}$ & 25 \\
\hline 6 & Cellulomonas cellulans ${ }^{*}$ & 25 \\
\hline 7 & Bacillus licheniformis $* *$ & 25 \\
\hline 8 & Bacillus spp* & 24 \\
\hline 9 & Bacillus spp* & 24 \\
\hline 10 & Penibacillus spp. * & 21 \\
\hline 11 & ? Clostridium spp.* & 22 \\
\hline 12 & Bacillus spp.** & 23 \\
\hline 13 & ? Clostridium spp.** & 21 \\
\hline 14 & Bacillus subtilis** & 25 \\
\hline 15 & Bacillus spp. ${ }^{*}$ & 22 \\
\hline 16 & Bacillus subtilis** & 25 \\
\hline 17 & Amphibacillus spp. ${ }^{* *}$ & 20 \\
\hline 18 & Cellulomonas cellulans $* *$ & 25 \\
\hline 19 & Bacillus spp. ** & 23 \\
\hline 20 & Amphibacillus spp. ** & 21 \\
\hline 21 & Bacillus subtilis* & 26 \\
\hline 22 & Geobacillus spp. * & 22 \\
\hline 23 & Bacillus spp. ** & 24 \\
\hline 24 & Bacillus spp. ** & 23 \\
\hline 25 & Penibacillus spp. ** & 22 \\
\hline
\end{tabular}

$*=$ Thermophilic and $* *=$ Thermotolerant $\quad ?=$ suspected

\section{Effect of Temperature:}

The temperature profile between $30^{\circ} \mathrm{C}$ and $80^{\circ} \mathrm{C}$, for Cellulase activity, at optimum $\mathrm{pH}$ was determined. The soluble enzyme extract was incubated with the substrate (CMC) at various temperatures $\left(30-80^{\circ} \mathrm{C}\right.$ ) (Oyekola, 2003 and Ray et al., 2007; Ariffin et al., 2006).

\section{Effect of pH:}

In order to determine the optimum assay $\mathrm{pH}$, for cellulase activity, the assay was carried out at different buffers used at various $\mathrm{pH}$ were: $0.05 \mathrm{M}$ sodium acetate $(\mathrm{pH}$ 3-4.5), 0.05 M sodium citrate ( $\mathrm{pH}$ 5-5.5) and 0.05 M sodium phosphate buffer (pH 6-8) (Oyekola, 2003; Ray et al., 2007; Ariffin et al., 2006).

\section{RESULT}

In the present study 10 thermophilic and 15 thermotolerant bacteria were isolated from compost piles. They were identified as Bacillus subtilis, Bacillus licheniformis, Bacillus spp., Cellulomonas cellulans, Geobacillus spp. and Penibacillus spp. were common bacteria. The most potent thermophilic cellulolytic isolates was Bacillus subtilis (Table 1) McCaig et al., (2001); Song et al., (2001).

\section{Production Optimization of Cellulase Enzyme}

The Bacillus subtilis produced maximum reducing sugar and also showed highest zone of hydrolysis as $21 \mathrm{~mm}$ in $8^{\text {th }}$ day at optimal cellulose basal medium.

In all four different cellulose basal media used for enzyme production Bacillus subtilis, produced highest enzyme activity in the medium as described by Ray et al., (2007). The zone of hydrolysis was $30 \mathrm{~mm}$.

\section{Optimum pH for maximum activity of Partial Purification of Enzyme}

The highest cellulolytic activity of crude enzyme (1:10 diluted) was given by the residue obtained by at 80 $\%$ ammonium sulfate precipitation at $4^{\circ} \mathrm{C}$. protein concentration of the residue was $0.865 \mathrm{mg} / \mathrm{ml}$ (Aboul-Enein et al., 2010)

The enzyme activity of Bacillus subtilis, was maximum at $\mathrm{pH} 7.2$ at $50^{\circ} \mathrm{C}$. However, Bacillus subtilis, retained its activity from 6.6 upto $9.0 \mathrm{pH}$.

\section{Thermostability of enzyme}

Cellulase enzyme activity of Bacillus subtilis was optimum at $50^{\circ} \mathrm{C}$. However, the result was similar as reported previously (Marques et al., 2003 and Murashima et al., 2002).

\section{DISCUSSION}

Bacillus subtilis, was potent thermophilic cellulytic bacteria. Cellulase enzyme activity of $B$. subtilis was optimum at $\mathrm{pH} 7.2$ at $50^{\circ} \mathrm{C}$ at $1 \% \mathrm{CMC}$ substrate concentration. The potential enzymatic degradation of cellulosic wastes by the thermotolent cellulase enzymes has been suggested as a feasible alternative for the conversion of lignocellulosics into fermentable sugars and fuel ethanol.

\section{ACKNOWLEDGEMENTS}

We acknowledge support of Central Department of Microbiology, Tribhuwan University (CDM-TU) and Nepal Academy of Science and Technology (NAST), Khumaltar, Lalitpur

\section{REFERENCES}

Aboul-Enein, A., Abou Elalla, F., Serour, E. and Hussien, T. 2010. Purification and Characterization of a Novel Thermoactive Cellulase from Thermophilic Actinomycetes Isolated from Soil Sample of Egypt International Journal of Academic Research. 2(1): 81-86.

Al-Tai, AM., Aabdul-Nour, BA. and Abdul-Razzak, SH. 1989. Cellulase Production from Actinomycetes Isolated from Iraqi Soils: I Characterization of A Cellulolytic Streptomyces Sp. Strain At7. Journal of Islamic Academy of Sciences. 2(2):109-112.

Ariffin, H., Abdullah, N., Umi Kalsom, MS., Shirai, Y. and Hassan, MA. 2006. Production and Characterization of Cellulase By Bacillus pumilus EB3. International Journal of Engineering and Technology. 3(1): 47-53.

Basic Organic Chemistry Laboratory Course. 2007. Identification Reactions and Qualitative Analysis. Department of Chemistry, 
University of Helsinki. 10-11.

Bergey’s manual determinative bacteriology. 2000. Actinomycetales. $\mathbf{9}^{\text {th }}$ edition.

Bhat, MK. 2000. Cellulases and related enzymes in biotechnology. Biotechnology Adv 18: 355-383.

Bradford, MM. 1976. A rapid sensitive method for the quantification of microgram quantities of protein utilizing the principle of proteindye binding. Analytical Biochemistry. 72: 248-251.

Coughlan, M. 1985. Cellulases: production, properties and applications. Biochemical Society Transactions. 13: 405-406.

El-Sersy, NA., Abd-Elnaby, H., Abou-Elela, GM., Ibrahim, HAH. and El-Toukhy, NMK. 2010. Optimization, economization and characterization of cellulase produced by marine Streptomyces ruber African Journal of Biotechnology. 9(38): 6355-6364.

Emtiazi, G., Pooyan, M. and Shamalnasab, M. 2007. Cellulase Activities in Nitrogen Fixing Paenibacillus isolated from Soil in Nfree Media. World Journal of Agricultural Sciences. 3 (5): 602-608.

Ghazifard, A., Kermanshahi, RK. and Etemadi, Z. 2001. Identification of thermophilic and mesophilic bacteria and fungi in Esfahan (Iran) municipal solid waste compost. Far Waste Management \& Research. 19(3): 257-261.

Ghazifard, A., Kermanshahi, RK. and Etemadi, Z. 2001. Identification of thermophilic and mesophilic bacteria and fungi in Esfahan (Iran) municipal solid waste compost. Far Waste Management \& Research. 19(3): 257-261.

Ghosh, TK. 1987. Measurement of cellulase activities. Pure Appl Chem. 59: 257-268.

Godana, B., Mitra, R. and Singh, S. 2007. Production of Enzymes for Application on Animal Feeds. Submitted in partial fulfillment of the requirements for the degree of Master of Technology (Biotechnology), Department of Biotechnology, Faculty of Science, Engineering and the Built Environment, Durban University of Technology, Durban, South Africa.

Haki, GD. and Rakshit, SK. 2003. Developments in industrially important thermostable enzymes: Bioresource Technology. 89: 1734.

Ibrahim, ASS. and El-diwany, AI. 2007. Isolation and identification of new cellulases producing thermophilic bacteria from Egyptian hot spring and some properties of the crude enzyme. Australian Journal of Basic and Applied Sciences. 1(4): 473-478.

Mach, RL., Zeilinger, S. 2003. Regulation of gene expression in industrial fungi: Trichoderma. Appl Microbiol Biotechnol. 60: 515522.

Maheshwari, R., Bharadwaj, G. and Bhat, MK. 2000. Thermophilic fungi: their physiology and enzymes. Microbiol Mol Biol Rev. 64: 461-488.

McCaig, AE., Grayston, SJ., Prosser, JI. and Glover, LA. 2001. Impact of cultivation on characterisation of species composition of soil bacterial communities, FEMS Microbiology Ecology. 35: 37-48.

Miller, GL. 1959. Use of dinitrosalicylic acid reagent for determination of reducing sugars. Anal Chem. 31: 426-429.

Mosier, NS., Hall, P., Ladisch, CM. and Ladisch, MR. 1999. Reaction kinetics, molecular action, and mechanisms of cellulolytic proteins. Advances in Biochemical Engineering/Biotechnology. 65: 23-40.
Muthuvelayudham, R. and Viruthagiri, T. 2006. Fermentative production and kinetics of cellulase protein on Trichoderma reesei using sugarcane bagasse and rice straw. African Journal of Biotechnology. 5 (20): 1873-1881.

Narasimha, G., Sridevi, A., Buddolla, Viswanath., Subhosh Chandra, M. and Rajasekhar, Reddy. 2006. Nutrient effects on production of cellulolytic enzymes by Aspergillus niger. African Journal of Biotechnology. 5 (5): 472-476.

Nascimento, RP., Junior, NA., Pereira, NJ., Bon, EPS. and Coelho, RRR. 2009. Brewer's spent grain and corn steep liquor as substrates for cellulolytic enzymes production by Streptomyces malaysiensis. Letters in Applied Microbiology. 48: 529-535.

Omojasola, PF., Jilani, OP. and Ibiyemi, SA. 2008. Cellulase production by some fungi cultured on pineapple waste. Nature Sci. 6: 64-69.

Oyekola, O. 2003. The Enzymology of Sludge Solubilisation under Biosulphidogenic Conditions: Isolation, Characterisation and Partial Purification of Endoglucanases. A thesis submitted in fulfillment of the requirements for the degree of Master of Science of Rhodes University in the Department of Biochemistry, Microbiology and Biotechnology. 1-125.

Patle, S. and Lal, B. 2007. Ethanol production from hydrolysed agricultural wastes using mixed culture of Zymomonas mobilis and Candida tropicalis. Biotechnology Letters. 29(12): 1839-1843.

Rajoka, MI. 2005. The enzymatic hydrolysis and fermentation of pretreated wheat straw and bagasse to ethanol. ATDF Journal. 2(2): 29-35.

Ray, AK., Abhinanda Bairagi, A., Ghosh, KS. and Sen, SK. 2007. Optimization of Fermentation Conditions for Cellulase Production by Bacillus Subtilis Cy5 and Bacillus Circulans Tp3 Isolated from Fish Gut. Acta Ichthyologica Et Piscatoria. 37 (1): 47-53.

Ryckeboer, J., Mergaert, J., Coosemans, J., Deprins, K. and Swings, J. 2003. Microbiological aspects of biowaste during composting in monitored compost bin. Journal of Applied Microbiology. 94: 127137.

Shaikh, AS., Khire, MJ. and Khan, IM. 1999. Characterization of a thermostable extracellular â-galactosidase from a thermophilic fungus Rhizomucor sp. Biochimica et Biophysica Acta (BBA) - General Subjects. 1472(1-2): 314-32.

Song, J., Weon, HY., Yoon, SH., Park, DS., Go, SJ. and Suh, TW. 2001. Phylogenetic diversity of thermophilic actinomycetes and Thermoactinomyces spp. isolated from mushroom composts in Korea based on 16S rRNA gene sequence analysis. FEMS Microbiology Letters. 202: 97-102.

Willium, ST., Sharpe, ME. and Baltimore, Md., Williums and Williums. 1986. Bergey's manual of systematic bacteriology. $4^{\text {th }}$ ed Holt JG editor.

Wood, TM. and Bhat, KM. 1988. Methods for measuring cellulase activities. In: Methods in Enzymology. Wood WA and Kellogg ST (Eds). Academic press. 160: 87-112

Zaldívar, M., Velásquez, JC., Contreras, I. and Pérez, LM. 2001. Trichoderma aureoviride 7-121, a mutant with enhanced production of lytic enzymes: its potential use in waste cellulose degradation and/ or biocontrol. Electronic journal of Biotechnology. 4(30): 161-168. 